\title{
Application of Kumon Learning Model to Improve Student Learning Outcomes in Economic Math Subject
}

\author{
Nur Fajri ${ }^{\mathrm{a}, 1, *}$, Asmaidi $^{\mathrm{b}, 2}$ \\ a STIMI Meulaboh, Meulaboh-Tapaktuan Street, Langung, 23681, Indonesia \\ ${ }^{b}$ Polytechnic of South Aceh, Merdeka Street, Komplek Reklamasi Pantai, Tapaktuan city, 23751, Indonesia \\ 1nurfajri.ifar@gmail.com;asmedmat@gmail.com
}

This research aims to study the effectiveness of Kumon learning model against the increase of student grade at Economic Math subject at STIMI Meulaboh. A quasi-experiment method with a pretest-posttest is used. The population used by the model is students of Management Economics at STIMI Meulaboh that follow Economic Math subject at the odd semester of the 2018/2019 school year. The students in Room 1 consist of 30 students who are chosen as the sample. The test instrument is used to collect the data for research. The research implementation procedure provides a pretest

Keywords:

Kumon Learning

Economic Math

Learning Result at the beginning of the meeting and compares the result with the posttest after Kumon learning model is applied to all samples. The result of pretest and posttest are used as research data. The research result points out that Kumon Learning Model helps students to increase their grades at Economic Math subject at STIMI Meulaboh.

Copyright (C) 2020 Politeknik Aceh Selatan. All rights reserved.

\section{Introduction}

Education is a need that must be fulfilled throughout life without education is impossible for humans to live and develop. Education is never separated from the words learning and teaching. Learning is a process of change in human personality, and the change is manifested in the form of increasing the quality and quantity of behavior such as increasing skills, knowledge, attitudes, habits, comprehension, skills, thinking power, and other abilities, while teaching instilling knowledge in students in the hope of understanding.

Mathematics is a science that deals with abstract concepts arranged in hierarchical and deductive reasoning that requires gradual and sequential understanding. This makes students think that mathematics is a tricky subject. Many complaints from students about mathematics are awkward, unattractive, dull, and feared by many children. Complex calculations and complicated formulas make many children dislike math.

Economic Mathematics is one part of mathematics that must be taken by students programmed in economic management studies at Sekolah Tinggi Ilmu Manajemen Indonesia (STIMI) Meulaboh. Efforts to overcome the difficulties of learning mathematics and improve the quality of education include implementing a learning model or method that can improve student learning activities.

The method is a way or sequence to achieve the goals. The teacher needs teaching and learning activities methods, and their use varies according to the objectives to be achieved after teaching ends. A teacher will not be able to carry out their duties if he does not master any of the teaching methods that have been formulated and put forward by psychologists and education experts [1]. 
One learning method that enhances student learning outcomes is the Kumon learning method. This method originates from Japan, which is considered useful in increasing children's mathematical abilities in school. The Kumon learning model emphasizes its activities on the abilities of each student, so students can explore their potential and develop their abilities to the full. According to [2], they are learning Models as learning activities that make teachers and students engage aimed for an effective and efficient learning outcome.

According to [3] the Kumon learning model is a learning system that provides individual learning programs according to their abilities, which allows children to explore their potential and develop their abilities to the maximum. Through Mathematics and English lessons, Kumon forms not only academic abilities but also forms positive characters that are useful for children's future. According to [4] Kumon learning model is a learning model that links a concept, skills, individual work, and a comfortable and pleasant atmosphere. According to [5], the implementation of the Kumon method engages students actively in the sequences of learning activity.

Kumon strives to improve each child's ability and maximize their potential. By exploring the potential of each individual, Kumon encourages children to be the best with their own abilities. Kumon values independent learning. Thus, individual tutoring is one of the basic features of the Kumon learning model. The key to individual learning is learning at the right level; students can learn independently without being specifically taught. This learning model defines the ability of independent learning as the ability to set goals and solve difficult problems independently. With the Kumon method, students can progress on their own without having to be specifically taught. Students find joy and satisfaction after reaching the target with their own abilities. In helping develop students' academic abilities, the most important thing is to make students enjoy their learning. By getting perfect grades at the right level, students can feel the joy and satisfaction of reaching the target with their own abilities.

According to [6] the steps of the Kumon learning model are as follows:

1. First, the teacher presents the concept and students pay attention to the presentation.

2. Then students take the pocketbook that has been provided, submit homework worksheets that have been done at home, and take worksheets that the teacher has prepared for students to do on that day.

3. After completing the work, the worksheet is submitted to the teacher to be checked and given a grade. While the worksheet is assessed, students practice with learning aids.

4. After the worksheets are checked and scored, the teacher records the learning outcomes of the day on the "grade list." These results will later be analyzed for the preparation of the next learning program.

5. If there are parts that are still wrong, students are asked to correct that section until all the worksheets score 100. The goal is that students master the lesson and not repeat the same mistakes.

6. If you repeat five times, the teacher approaches the student and asks about the difficulties encountered.

7. After completing, students take the exercise verbally. Before leaving, the teacher gives an evaluation of the student's work that day and tells the material to be done the next day.

8. The Kumon Method has a specialty as follow:

9. Starting from the right level will foster a love of learning.

10. According to ability, because before the child learns, there is a placement test.

11 . We are going forward with your own abilities.

12. The lesson material is composed of small steps so as to obtain a strong basic ability to reach a higher level.

13. The Kumon worksheet is structured to foster an attitude of independent learning.

14. Children work on problems independently gradually from the easy level to a more difficult level.

15. Develop good study habits and independent study skills.

16. Go beyond the grade level.

17. In Kumon, parents play a very important role. 
18. Continuous learning with the Kumon method will be beneficial in shaping the child's future.

\section{Research Method}

According to [7], the experimental method is widely used in natural science. Experiments can be done even out of the laboratory. The method in this study is a quasi-experimental method with a pretest-posttest research design. The subject will be given a pretest first to see the comparison with the posttest. After the pretest, the subject will be given teaching material using the Kumon learning method.

After the research data is collected, it is then processed using statistics. Data processing activity begins with tabulating data that has been collected into a distribution list, and the steps are as follows:

1. Make a frequency distribution table with the same class length, then according to [8], it is determined first:

a. Range, i.e. big data minus smallest data.

b. The number of interval classes required. For that use the Sturges rules, namely:

Number of classes $=1+(3,3) \log n$

The length of the interval class $P$

$$
P=\frac{\text { Range }}{\text { numbers of clasegs }}
$$

c. The lower end of the first interval class. To be selected, it must be the same as the smallest data or a smaller data value than the smallest data, but the difference must be less than the specified class length.

2. Determine the average value ( $\mathrm{x})$ and standard deviation $(\mathrm{s})$

To find an average formula will be used.

$$
\bar{x}=x_{0}+p\left(\frac{\sum f_{1} \sigma_{l}}{n}\right)
$$

Whereas to determine the standard deviation (s) with the following formula:

$$
s=P \sqrt{\frac{\sum \text { fici }}{n}-\left(\frac{\sum f i c i}{n}\right)^{2}}
$$

$\mathrm{s}:$ Standard deviation

$\mathrm{p}$ : Range

$\mathrm{f}_{\mathrm{i}}$ : Frequency

$\mathrm{c}_{\mathrm{i}}$ : Code value

$\mathrm{n}$ : Total students

To determine the homogeneity of variance. According to [8], the Homogeneity test is conducted to know that population, whether it is homogenous or is not homogenous. The formula used is:

$$
\mathrm{F}=\frac{\text { Larger Varians }}{\text { smallar Varians }}
$$

with the hypothesis formulation as follows:

$\mathrm{H}_{0}: \sigma_{1}^{2}=a_{2}^{2}$ The variance of students who get Kumon learning is the same as the variance before obtaining the Kumon learning model.

$\mathrm{H}_{1}: a_{1}^{2}>a_{2}^{2} \quad$ The variance of students who obtained the Kumon learning model was better than the variance before obtaining the Kumon learning model.

Because the test is a right-party test, the applicable test criteria are: "Reject $\mathrm{H}_{0}$ if $\mathrm{F}_{\text {count }} \geq \mathrm{F}_{\alpha}$ (n1-1, n2-1) and accept $\mathrm{H}_{0}$ if $\mathrm{F}$ has other prices with a real level $\alpha=0.05$. Hypothesis testing in this

Fajri, Nur et al. (Application of Kumon Learning Model to Improve Student Learning Outcomes in Economic Math Subject) 
study uses a two-tailed t-test (left side and right side), with a significant level of $\alpha=0.05$. The test is an average of $\mu_{1}$ and $\mu_{2}$, the pair of null hypotheses and the match is:

$\mathrm{H}_{0}: \mu_{1}=\mu_{2} \quad$ Learning outcomes of students who get Kumon learning is the same as before Kumon learning model.

$\mathrm{H}_{1}: \mu_{1}>\mu_{2} \quad$ Student learning outcomes that get the Kumon learning model better than before obtaining the Kumon learning model.

Hypothesis testing can be used t-test as follows:

Where:

$$
t=\frac{\bar{x}_{1}-\bar{x}_{2}}{\sqrt{\frac{s_{1}^{2}}{n_{1}}+\frac{s_{2}^{2}}{n_{2}}}}
$$

$\bar{x}:$ Mean

$\mathrm{s}:$ standard deviation

$\mathrm{n}_{1}$ : Total data 1 $\mathrm{n}_{2}-2$.

The testing criteria are accept $\mathrm{H}_{0}$ if $\mathrm{t}<\mathrm{t}_{1-\alpha}$ and reject $\mathrm{H}_{0}$ if $\mathrm{t}$ has other prices. With $\mathrm{dk}=\mathrm{n}_{1}+$

\section{Results and Discussion}

Before conducting the research, the following things are done first. The researcher designed an instrument that would be used as a tool to retrieve data, a test item consisting of 5 item descriptions. The data obtained from the results of the study are as follows:

Pretest value before applying Kumon learning model:

$\begin{array}{ccccccccccc}50 & 40 & 60 & 65 & 60 & 40 & 45 & 30 & 35 & 45 & 55 \\ 50 & 60 & 55 & 53 & 45 & 60 & 56 & 35 & 45 & 55 & 45 \\ 45 & 50 & 40 & 37 & 45 & 50 & 43 & 60 & & & \end{array}$

Post-test value after the application of the kumon learning model:

$\begin{array}{lllllllllll}75 & 60 & 75 & 60 & 68 & 95 & 75 & 70 & 80 & 70 & 90 \\ 65 & 75 & 68 & 58 & 55 & 94 & 76 & 68 & 70 & 50 & 95 \\ 70 & 68 & 73 & 58 & 70 & 64 & 57 & 65 & & & \end{array}$

III.1 Calculation of Average and Test Variance

\subsection{Pretest Score}

Table 1 Pretest Frequency Distribution List

\begin{tabular}{cccccccc}
\hline NO & TEST SCORE & $\begin{array}{c}\text { FREQUENCY } \\
\left(\mathrm{F}_{\mathrm{I}}\right)\end{array}$ & $\begin{array}{c}\text { MIDDLE } \\
\text { VALUE }\left(\mathrm{X}_{\mathrm{I}}\right)\end{array}$ & $\mathrm{D}_{\mathrm{I}}$ & $\mathrm{C}_{\mathrm{I}}$ & $\mathrm{F}_{\mathrm{I}} \mathrm{C}_{\mathrm{I}}$ & $\mathrm{F}_{\mathrm{I}} \mathrm{C}_{\mathrm{I}}{ }^{2}$ \\
\hline 1 & $30-36$ & 3 & 33 & -20 & -2 & -6 & 12 \\
\hline 2 & $37-43$ & 5 & 40 & -10 & -1 & -5 & 5 \\
\hline 3 & $44-50$ & 11 & 47 & 0 & 0 & 0 & 0 \\
\hline 4 & $51-57$ & 5 & 54 & 10 & 1 & 5 & 5 \\
\hline 5 & $58-64$ & 5 & 61 & 20 & 2 & 10 & 20 \\
\hline 6 & $65-71$ & 1 & 68 & 30 & 3 & 3 & 9 \\
\hline & SUM & 30 & - & - & - & 7 & 51 \\
\hline
\end{tabular}


Based on Table 1 obtained an average ( $\bar{x}$ ) for the pretest value of 48.6 variance $\left(\mathrm{s}^{2}\right) 80,28$ and standard deviation (s) 8,96 .

\subsection{Posttest Score}

Table 2. Posttest Frequency Distribution List

\begin{tabular}{cccccccc}
\hline \multirow{2}{*}{ No } & $\begin{array}{c}\text { TEST } \\
\text { SCORE }\end{array}$ & $\begin{array}{c}\text { FREQUENCY } \\
\left(\mathrm{F}_{\mathrm{I}}\right)\end{array}$ & $\begin{array}{c}\text { MIDDLE VALUE } \\
\left(\mathrm{X}_{\mathrm{I}}\right)\end{array}$ & $\mathrm{D}_{\mathrm{I}}$ & $\mathrm{C}_{\mathrm{I}}$ & $\mathrm{F}_{\mathrm{I}} \mathrm{C}_{\mathrm{I}}$ & $\mathrm{F}_{\mathrm{I}} \mathrm{C}_{\mathrm{I}}{ }^{2}$ \\
\hline 1 & $50-58$ & 3 & 54 & -20 & -2 & -6 & 12 \\
\hline 2 & $59-67$ & 6 & 63 & -10 & -1 & -6 & 6 \\
\hline 3 & $68-76$ & 16 & 72 & 0 & 0 & 0 & 0 \\
\hline 4 & $77-85$ & 1 & 81 & 10 & 1 & 1 & 1 \\
\hline 5 & $86-94$ & 2 & 90 & 20 & 2 & 4 & 8 \\
\hline 6 & $95-103$ & 2 & 99 & 30 & 3 & 6 & 18 \\
\hline JUMLAH & 30 & - & - & - & -1 & 45 \\
\hline
\end{tabular}

Based on Table 2 obtained an average ( $\bar{x}$ ) for the posttest value 70.57 variance $\left(\mathrm{s}^{2}\right) 120,56$ and standard deviation (s) 11.515

\subsection{Homogeneity Test}

The homogeneity variance test aims to determine whether the sample from this study came from the same population so that the generalizations of the results of this study are valid for the population.

The hypothesis will be tested at a significant level of $\alpha=0.05$, i.e:

$$
\begin{aligned}
& \mathrm{H}_{0}: a_{1}^{2}=a_{2}^{2} \\
& \mathrm{H}_{1}: \sigma_{1}^{2}>a_{2}^{2}
\end{aligned}
$$

Because this test is a right-hand test, the test criteria are "Reject $\mathrm{H}_{0}$ if $\mathrm{F}_{\text {count }} \geq \mathrm{Fr}\left(\mathrm{n}_{1}-1, \mathrm{n}_{2}-1\right)$ and accept $\mathrm{H}_{0}$ if $\mathrm{F}$ has other prices". Based on the above calculation, variance has been obtained from each group $\mathrm{s}_{1}{ }^{2}=80,28$ and $\mathrm{s}_{2}{ }^{2}=120,56$ so:

$$
\begin{aligned}
& \mathrm{F}=\frac{\text { harger varians }}{\text { amaller varians }} \\
& \mathrm{F}=\frac{100,56}{80,20} \\
& \mathrm{~F}=1,50
\end{aligned}
$$

From the distribution table obtained $F_{z x}\left(\mathrm{n}_{1}-1, \mathrm{n}_{2}-1\right)=\mathrm{F}_{0,05}(29,29)$

$$
=1,85
$$

It turns out that $\mathrm{F}_{\text {count }}<\mathrm{F}_{\text {table }}(1,50<1,85)$, then $\mathrm{H}_{0}$ is accepted and it can be concluded that both variances are homogeneous for the pretest and posttest.

\subsection{Normality Test}

A normality test is a test conducted with the aim to assess the distribution of data in a group of data or variables, whether the data distribution is normally distributed or not. According to [9], the Normality test is conducted to know the normality of data distribution. The normality test in this study uses the Kolmogorov-Smirnov Z test with the help of SPSS 20. The basis for decision making in the Kolmogorov-Smirnov $\mathrm{Z}$ normality test is as follows:

a. If the significant value (sig) is greater than 0.05 , the research data is normally distributed. 
b. Conversely, if the significant value (sig) is smaller than 0.05 , the research data is not normally distributed.

1. Test the normality for the pretest value

Kolmogorov-Smirnov $Z$ test for the pretest value with the help of SPSS 20 obtained a significant value of 0.812 . This shows that the sig value of more than 0.05 means that the pretest value in this study is normally distributed.

2. Test the normality for the posttest value

To test the normality of the posttest value obtained with a significance value of 0.071 , where the sig value of $0.071>0.05$, this means that the posttest value in this study is normally distributed.

\subsection{Hypothesis Test}

To test the hypothesis of this study, researchers used the t-statistic at a significant level of $\alpha=0.05$. The t-statistic hypothesis was tested using a two-part test. The hypothesis used in this study is as follows:

$\mathrm{H}_{0}: \mu_{1}=\mu_{2} \quad$ Learning outcomes of students who get Kumon learning is the same as before getting a Kumon learning model

$\mathrm{H}_{1}: \mu_{1}>\mu_{2} \quad$ Student learning outcomes that get the Kumon learning model better than before obtaining the Kumon learning model

With the value of $t$ as follows:

$$
\begin{aligned}
& t=\frac{\bar{x}_{1}-\bar{x}_{2}}{\sqrt{\frac{s_{1}^{2}{ }^{2}+\frac{g_{2}^{2}}{n_{1}}}{n_{2}}}} \\
& t=\frac{70,57-48,43}{\sqrt{\frac{132,6}{30}+\frac{80,87}{30}}} \\
& t=8,2
\end{aligned}
$$

With significant $a=0,05$ and degrees of freedom $\mathrm{dk}=\mathrm{n}_{1}+\mathrm{n}_{2}-2$ then from the $\mathrm{t}$ distribution by interpolation $t_{0,95}(58)=1,67$, so obtained $t_{\text {hitung }}>t_{\text {tabel }}(8,2>1,67)$ then $H_{0}$ is rejected with significant $a=0,05$. So it can be concluded that "student learning outcomes that get the Kumon learning model better than before obtaining the Kumon learning model in the Mathematics-Economics Subject at STIMI Meulaboh.

\section{Conclusion}

Based on the results of research and discussion, it can be concluded that:

1. Student learning outcomes using the Kumon learning model in economics mathematics courses achieve learning completion criteria.

2. The average learning outcomes of the Kumon learning model are better than the average conventional learning outcomes.

\section{Acknowledgment}

Thank you to the Chairperson of the STIMI Management Economics Study Program, Meulaboh. My thanks to my fellow lecturers who have guided and assisted in the publication of my journal. Hopefully, I get this guidance and assistance to improve myself in future journal publications.

\section{References}

[1] Djamarah. 2002. Strategi Belajar Megajar. Jakarta: Rineka Cipta. 
[2] Isjoni. 2012. "Efektivitas Model Kooperatif dalam Pelajaran Sejarah di Sekolah". Dalam Isjoni dan M. A. Hj. Ismail, Model-Model Pembelajaran Mutakhir: Perpaduan Indonesia-Malaysia (pp. 145--170). Yogyakarta: Pustaka Pelajar.

[3] Lukman. 2008. Bagaimana Penepan Metode Kumon Itu.

$\mathrm{http} / / /$ kurikulumberbasis.wordpress.com/2008/07/07bagaimanakah-penerapan-metode-kumonitu/.Diakses 8 Agustus 2019.

[4] Herdian.2019. Model Pembelajaran Kumon https://herdy07.wordpress.com/2009/04/29/model-pembelajara-kumon/.Diakses pada tanggal 8 agustus.

Haryanti, YD, Nurjanah S. 2018. Model Kumon untuk Meningkatkan Pemahaman Konsep Materi Pecahan Siswa Kelas III di SD Negeri Majalengka Kulon VII. Jurnal Taman Cendikia. 2(2), Desember 2018, e-ISSN 2579-5147. Universitas Sarjanawiyata Tamansiswa.

[5] Shoimin, Aris. 2016. Model Pembelajaran Inovatif dalal Kurikulum 2013. Yogyakarta: ArRuzz Media.

[6] Seriati, KY, Margiati, Kresnadi, H. 2014. Penggunaan Metode Eksperimen Untuk Meningkatkan Hasil Belajar Siswa Pada Mata Pelajaran IPA di SD. Program Studi Pendidikan Guru Sekolah Dasar Jurusan Pendidikan Dasar Fakultas Keguruan dan Ilmu Pendidikan Universitas Tanjungpura Pontianak.

[7] Sudjana. 2002. Metode Statistik. Bandung: Tarsito. Jakarta.

[8] Amaliah, R. 2017. Hasil Belajar Biologi Materi Sistem Gerak Dengan Menerapkan Model Pembelajaran Kooperatif Tipe Rotating Trio Exchange (RTE) Pada Siswa Kelas XI SMAN 4 Bantimurung. Jurnal Dinamika. 8(1), April 2017, e-ISSN 2503-4863. UNNES Journal.

[9] Rojihah, Akhrani, LA, Hasanah, N. 2015. Perbedaan Political Awareness Dilihat Dari Peran Gender Pemilih Pemula. JURNAL MEDIAPSI. 1(1), Desember 2015, Hal. 59-66. 